\title{
PEMODELAN MATEMATIKA PREMI TUNGGAL BERSIH ASURANSI UNIT LINK SYARIAH
}

\author{
Nanang Supriadi ${ }^{1}$ \\ ${ }^{1}$ Universitas Islam Negeri Raden Intan Lampung, nanangsupriadi@gmail.com \\ Submitted : 22-10-2017, Revised : 13-12-2017, Accepted : 19-12-2017
}

\begin{abstract}
The exact risk factor can be managed by transferring the risk to the other party (in this case the insurance company). In this paper will be discussed more about life insurance, as the development now there are types of insurance combined with investment, which is popular with the term Unit Link insurance. Unit link syariah began to be launched as one of the fulfillments of the high needs of the community, the privilege of the product Unit of Islamic links is actually located in the elements of the laws in accordance with Islamic syariah. The issues that will be discussed are how to get a single premium model of life insurance unit link syariah with life insurance and investment fund allocation invested in investment product with big interest rate of risk (financial approach) and investment product with value of return maximum (actuarial approach). The resulting model is then implemented in case examples by comparing the two approaches to see the shortcomings and advantages of Unit link lifetime life insurance when compared to life insurance. The result obtained from this research is the benefit obtained from Unit-linked sharia insurance on average will be greater if compared with life insurance for life, maximum benefit will be obtained Insurance Unit Link of sharia using actuarial approach compared to financial but benefit with relative financial approach more stable than actuarial approaches that tend to fluctuate.
\end{abstract}

Keywords : Actuarial; Financial; Unit Link; Premium.

\begin{abstract}
Abstrak
Faktor risiko yang pasti terjadi dapat dikelola dengan memindahkan risiko kepada pihak lain (dalam hal ini perusahaan asuransi). Pada tulisan ini akan dibahas lebih banyak tentang asuransi jiwa, seiring perkembangannya kini terdapat jenis asuransi yang digabung dengan investasi, yang populer dengan istilah asuransi Unit link. Unit link Syariah mulai diluncurkan sebagai salah satu pemenuhan terhadap tingginya kebutuhan masyarakat, keistimewaan dari produk Unit link syariah ini sebenarnya terletak pada unsur hukum-hukum yang sesuai dengan syariah Islam. Masalah yang akan dibahas yaitu bagaimana mendapatkan model premi tunggal bersih asuransi jiwa Unit link Syariah dengan jenis asuransi jiwa seumur hidup dan alokasi dana investasi yang ditanamkan pada produk investasi dengan suku bunga besar risiko (pendekatan finansial) dan produk investasi dengan nilai tingkat keuntungan (return) yang maksimal (pendekatan aktuarial). Model yang dihasilkan kemudian diimplementasikan dalam contoh kasus dengan membandingkan kedua pendekatan tersebut untuk melihat kekurangan dan
\end{abstract}


kelebihan dari asuransi jiwa seumur hidup Unit link jika dibandingkan dengan asuransi jiwa seumur hidup. Hasil yang diperoleh dari penelitian ini adalah benefit yang didapat dari asuransi Unit Link syariah secara rata-rata akan lebih besar jika dibandingkan dengan asuransi jiwa seumur hidup, benefit maksimal akan didapat asuransi Unit Link syariah menggunakan pendekatan aktuarial dibanding finansial, tetapi benefit dengan pendekatan finansial relatif lebih stabil dibanding pendekatan aktuarial yang cenderung berfluktuatif.

Kata Kunci : Aktuarial; Finansial; Unit Link; Premi.

\section{PENDAHULUAN}

Kehidupan manusia tidak terlepas dari faktor risiko yang pasti terjadi. Mulai dari risiko kehilangan aset atau harta, risiko sakit, cacat total hingga risiko kehilangan jiwa atau meninggal. Penyebabnya bisa secara alamiah (karena sakit) maupun karena kecelakaan dan ironisnya kita tidak pernah tahu kapan risiko itu akan terjadi. Allah SWT telah berfirman dalam surat Lukam ayat 34 yang berbunyi:

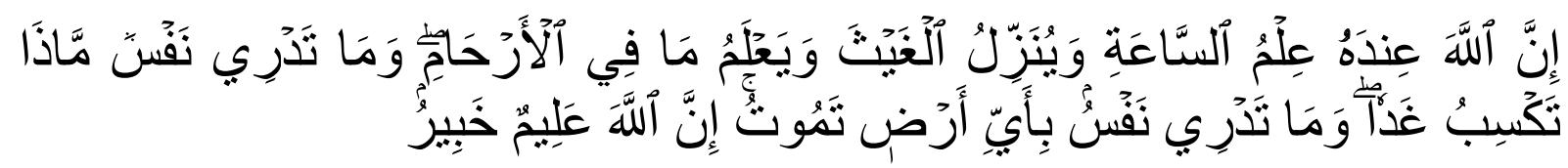

Artinya : "Sesungguhnya Allah, hanya pada sisi-Nya sajalah pengetahuan tentang Hari Kiamat; dan Dialah Yang menurunkan hujan, dan mengetahui apa yang ada dalam rahim. Dan tiada seorang pun yang dapat mengetahui (dengan pasti) apa yang akan diusahakannya besok. Dan tiada seorang pun yang dapat mengetahui di bumi mana dia akan mati. Sesungguhnya Allah Maha Mengetahui lagi Maha Mengenal" (Lukman:34)

Menurut Usman, F. \& Arif, M. (2004), manusia masih dapat melakukan pengelolaan risiko yaitu dengan memindahkan risiko kepada pihak lain (dalam hal ini perusahaan asuransi) merupakan salah satu cara. Pada kesempatan ini penulis akan lebih banyak memberikan perhatian pada jenis asuransi jiwa. Tujuan utama dari asuransi jiwa adalah untuk memberikan pertanggungan kepada pemegang polis dan keluarga mereka. Seiring perkembangannya kini terdapat jenis asuransi yang digabung dengan investasi, yang populer dengan istilah asuransi Unit link. Sendra, K. (2004) menyebutkan, asuransi Unit link pada dasarnya adalah suatu polis yang menggabungkan program proteksi, tabungan, dan investasi dalam satu produk. Investasi dalam asuransi Unit link secara garis besar terbagi menjadi dua, yaitu investasi dengan suku bunga yang bebas risiko dan investasi yang mengharapkan keuntungan (return) yang maksimal.

Unit link Syari'ah mulai diluncurkan sebagai salah satu pemenuhan terhadap tingginya kebutuhan masyarakat akan produk Unit link Syari'ah sebagai investasi alternatif yang memberikan return lebih menarik daripada produk investasi yang ada dalam perbankan. Ali, AM. \& Hasan, (2004) dan Hamdi, M.L. (2003) menyebutkan keistimewaan dari produk Unit link syariah ini sebenarnya terletak pada unsur hukum-hukum yang sesuai dengan syariah Islam. Perusahaan Asuransi syariah memanfaatkan kelebihan ini untuk menarik minat masyarakat yang memang mayoritas beragama Islam, sehingga banyak perusahaan asuransi 
yang berhasil meningkatkan penjualannya dan pendapatan asetnya berkat produk asuransi yang relatif baru ini.

Analisa teoritis pertama dari asuransi Unit link adalah Brennan, M.J. \& Schwartz, E.S. (1976) dan Boyle, P.P. \& Schwartz, E.S. (1977), mereka menerapkan metodologi Black-Scholes untuk menetapkan harga jaminan aset yang berkaitan dengan kebijakan-kebijakan asuransi jiwa. Perkembangan lebih lanjut dari analisa ini berasal dari Moller, T. (2003) yang memperkenalkan pengembangan teori terapan kontrak asuransi Unit link yang diistilahkan sebagai pendekatan finansial, di dalam pengertiannya bahwa asuransi ini bersandar pada nilai risiko finansial yang terlindungi. Perkembangan teoritis lainnya ialah dengan membandingkan pendekatan finansial dan pendekatan aktuarial yang bersandar pada asas kesetaraan. Hardy, M.R. (2000) di dalam tulisannya membandingkan kedua pendekatan tersebut dengan menggunakan Simulasi Monte Carlo.

Tulisan ini akan membahas bagaimana mendapatkan model premi tunggal bersih asuransi jiwa Unit link Syariah dengan jenis asuransi jiwa seumur hidup dan alokasi dana investasi yang ditanamkan pada produk investasi dengan suku bunga besar resiko (pendekatan finansial) dan produk investasi dengan nilai tingkat keuntungan (return) yang maksimal (pendekatan aktuarial). Model yang dihasilkan kemudian diimplementasikan dalam contoh kasus dengan membandingkan kedua pendekatan tersebut untuk melihat kekurangan dan kelebihan dari asuransi jiwa seumur hidup Unit link jika dibandingkan dengan asuransi jiwa seumur hidup.

\section{METODE PENELITIAN}

Tulisan ini merupakan studi pustaka yang merupakan telaah dari literatur. Rinaldi, A. (2015) dan Anggraini, D., \& Wijaya, Y. (2016) menyebutkan bahwa teknik pengumpulan data dalam studi pustaka dengan mengadakan studi penelaahan terhadap buku-buku literatur-literatur, catatan-catatan, jurnal-jurnal dan laporan-laporan yang ada hubungannya dengan masalah yang dipecahkan. Setelah informasi yang relevan ditemukan, peneliti kemudian mereview dan menyusun bahan pustaka sesuai dengan urutan kepentingan dan relevansinya dengan masalah yang sedang diteliti. Bahan-bahan informasi yang diperoleh kemudian dibaca, dicatat, diatur, dan ditulis kembali. Setelah model terbentuk, maka hal selanjutnya dilakukan yaitu dengan mengadakan simulasi guna menjawab rumusan masalah yang ada.

\section{HASIL PENELITIAN DAN PEMBAHASAN}

Kebanyakan praktik asuransi jiwa informasi yang dipakai untuk distribusi probabilitas T adalah tabel mortalitas waktu diskrit, sedangkan model harga saham untuk dua pendekatan adalah sebagai berikut:

1. Untuk Pendekatan aktuarial :

$$
\begin{aligned}
& d S_{k} / S_{k}=\mu d k+\sigma d w_{k} \\
& d S_{k}=\mu S_{k} d k+\sigma S_{k} d w_{k}
\end{aligned}
$$


dengan penyelesaian tunggal

$$
S_{k}=S_{0} \exp \left[\left(\mu-\frac{1}{2} \sigma^{2}\right) k+\sigma w_{k}\right]
$$

2. Untuk Pendekatan Finansial :

$$
\begin{aligned}
& d S_{k} / S_{k}=r d k+\sigma d w_{k} \\
& d S_{k}=r S_{k} d k+\sigma S_{k} d w_{k}
\end{aligned}
$$

dengan penyelesaian tunggal

$$
S_{k}=S_{0} \exp \left[\left(r-\frac{1}{2} \sigma^{2}\right) k+\sigma w_{k}\right]
$$

Berdasarkan definisi gerak brownian Lin, X. Sheldon, (2006) Lin, $w_{k} \sim N(0, k)$ maka $w_{k-0} \sim N(0, k-0)$ sehingga dari persamaan (2.2) dan (2.4) dengan menggunakan sifat ekspektasi didapatkan :

$$
\begin{aligned}
& \ln S_{k} \sim N\left[\left(\mu-\frac{1}{2} \sigma^{2}\right) k, \sigma^{2} k\right] \\
& \ln S_{k} \sim N\left[\left(r-\frac{1}{2} \sigma^{2}\right) k, \sigma^{2} k\right]
\end{aligned}
$$

dengan kata lain :

$$
\begin{aligned}
& S_{k} \sim \log -N\left[\left(\mu-\frac{1}{2} \sigma^{2}\right) k, \sigma^{2} k\right] \\
& S_{k} \sim \log -N\left[\left(\mu-\frac{1}{2} \sigma^{2}\right) k, \sigma^{2} k\right]
\end{aligned}
$$

Ini berarti bahwa hasil dari harga saham mengikuti suatu distribusi log-normal dengan parameter-parameter $\left(\mu-\sigma^{2} / 2\right) k$ dan $\sigma^{2} k$ untuk pendekatan aktuarial dan suatu distribusi log-normal dengan parameter-parameter $\left(r-\sigma^{2} / 2\right) k$ dan $\sigma^{2} k$ untuk pendekatan finansial.

Bowers, Newton L, dkk, (1997) dan Ochi, M. K. (1990), seperti yang telah diketahui bahwa premi tunggal bersih untuk asuransi jiwa seumur hidup adalah:

$$
A_{x}=E(Z)=\sum_{k=0}^{\infty} v_{k}^{k+1} p_{x} q_{x+k}
$$

Oleh karena asuransi ini adalah asuransi Unit Link yang sebagian nilai preminya diinvestasikan maka peran nilai fungsi diskonto $v^{k+1}$ pada asuransi jiwa seumur hidup dapat kita konversikan menjadi nilai investasi untuk asuransi Unit Link. Sedangkan fungsi kumulatifnya dimulai saat tahun pertama hingga nilai harapan sisa usia $\omega-x$, maka akan didapat suatu persamaan Premi Tunggal Bersih untuk pendekatan aktuarial dan finansial, yaitu :

$$
\begin{aligned}
& S P P^{A k t}=\sum_{k=1}^{\omega-x} V^{P}(0, k){ }_{k} p_{x} q_{x+k} \\
& S P P^{F i}=\sum_{k=1}^{\omega-x} V^{Q}(0, k){ }_{k} p_{x} q_{x+k}
\end{aligned}
$$

di mana :

$V^{P}(0, k) \quad=$ Nilai investasi dengan pendekatan aktuarial dari waktu ke-0 sampai waktu ke-k 

$V^{Q}(0, k) \quad=$ Nilai investasi dengan pendekatan finansial dari waktu ke-0 sampai waktu ke-k
${ }_{k} p_{x} \quad=$ Probabilitas seseorang yang sekarang berusia $x$ tahun akan hidup sampai $k$ tahun ke depan
$q_{x+k} \quad=$ Probabilitas seseorang yang sekarang berusia $(x+k)$ tahun akan meninggal 1 tahun yang akan datang

Berdasarkan teorema, nilai investasi dari Unit Link akan difokuskan sebagai nilai perlindungan aset, sehingga kita dapat mengetahui bahwa:

$V^{P}(0, k)=E_{P}\left[e^{-r k} \max \left\{K-S_{k}, 0\right\}\right]$

$V^{Q}(0, k)=E_{Q}\left[e^{-r k} \max \left\{K-S_{k}, 0\right\}\right]$

Nilai investasi antara kedua rumusan tersebut berada di bawah masing-masing ukuran:

a. $\mu$ di bawah $\mathrm{P}$ untuk pendekatan aktuarial,

b. $r$ di bawah $Q$ untuk pendekatan finansial.

Sehingga didapat persamaan nilai $V^{P}(0, k)$ dan $V^{Q}(0, k)$ yaitu:

$V^{Q}(0, k)=K e^{-r k} \Phi\left(-d_{2}\right)-S_{0} e^{(\mu-r) k} \Phi\left(-d_{1}\right)$

$V^{Q}(0, k)=K e^{-r k} \Phi\left(-d_{2}^{F i}(0, k)\right)-S_{0} \Phi\left(-d_{1}^{F i}(0, k)\right)$

Jadi kita memperoleh satu ungkapan Premi Tunggal Bersih (SPP) menurut masing-masing pendekatan, yaitu Supriadi, N., \& Gunardi, M. S. (2009):

$$
\begin{aligned}
S P P^{A k t} & =\sum_{k=1}^{\omega-x} V^{P}(0, k){ }_{k} p_{x} q_{x+k} \\
& =\sum_{k=1}^{T} K e^{-r k} \Phi\left(-d_{2}^{A k t}(0, k)\right)_{k} p_{x} q_{x+k}-S_{0} \sum_{k=1}^{T} e^{(\mu-r) k} \Phi\left(-d_{1}^{A k t}(0, k)\right){ }_{k} p_{x} q_{x+k}
\end{aligned}
$$

dengan:

$$
\begin{aligned}
& d_{1}^{A k t}(0, k)=\frac{\ln \left(\frac{S_{0}}{K}\right)+\left(\mu+\frac{1}{2} \sigma^{2}\right) k}{\sigma \sqrt{k}} \quad \text { dan } \quad d_{2}^{A k t}(0, k)=d_{1}^{A k t}(0, k)-\sigma \sqrt{k} \\
& S P P^{F i}=\sum_{k=1}^{\omega-x} V(0, k)_{k} p_{x} q_{x+k} \\
& =\sum_{k=1}^{T} K e^{-r k} \Phi\left(-d_{2}^{F i}(0, k)\right)_{k} p_{x} q_{x+k}-S_{0} \sum_{k=1}^{T} \Phi\left(-d_{1}^{F i}(0, k)\right)_{k} p_{x} q_{x+k}
\end{aligned}
$$

dengan :

$d_{1}^{F i}(0, k)=\frac{\ln \left(\frac{S_{0}}{K}\right)+\left(r+\frac{1}{2} \sigma^{2}\right) k}{\sigma \sqrt{k}} \quad$ dan $\quad d_{2}^{F i}(0, k)=d_{1}^{F i}(0, k)-\sigma \sqrt{k}$

Setelah model premi tunggal bersih asuransi jiwa Unit link Syariah dengan jenis asuransi jiwa seumur hidup menggunakan pendekatan finansial $\left(S P P^{F i}\right)$ dan pendekatan 
aktuarial $\left(S P P^{A k t}\right)$ didapat maka untuk melihat kelebihan dan kekurangan kedua pendekatan tersebut dilakukan simulasi dengan asumsi-asumsi sebagai berikut: seorang wanita berusia 30 tahun, tabel Mortalita 1999 Female, data saham harian selama setahun PT Telkom Tbk, return saham berdistribusi Normal, suku bunga bebas risiko $8 \%$, nilai saham saat $S_{0}=6.900$, harga kesepakatan $K=7.775$.

Asumsi-asumsi tersebut kemudian diimplementasikan pada model (14) dan (15) dengan hasil temuan sebagai berikut:

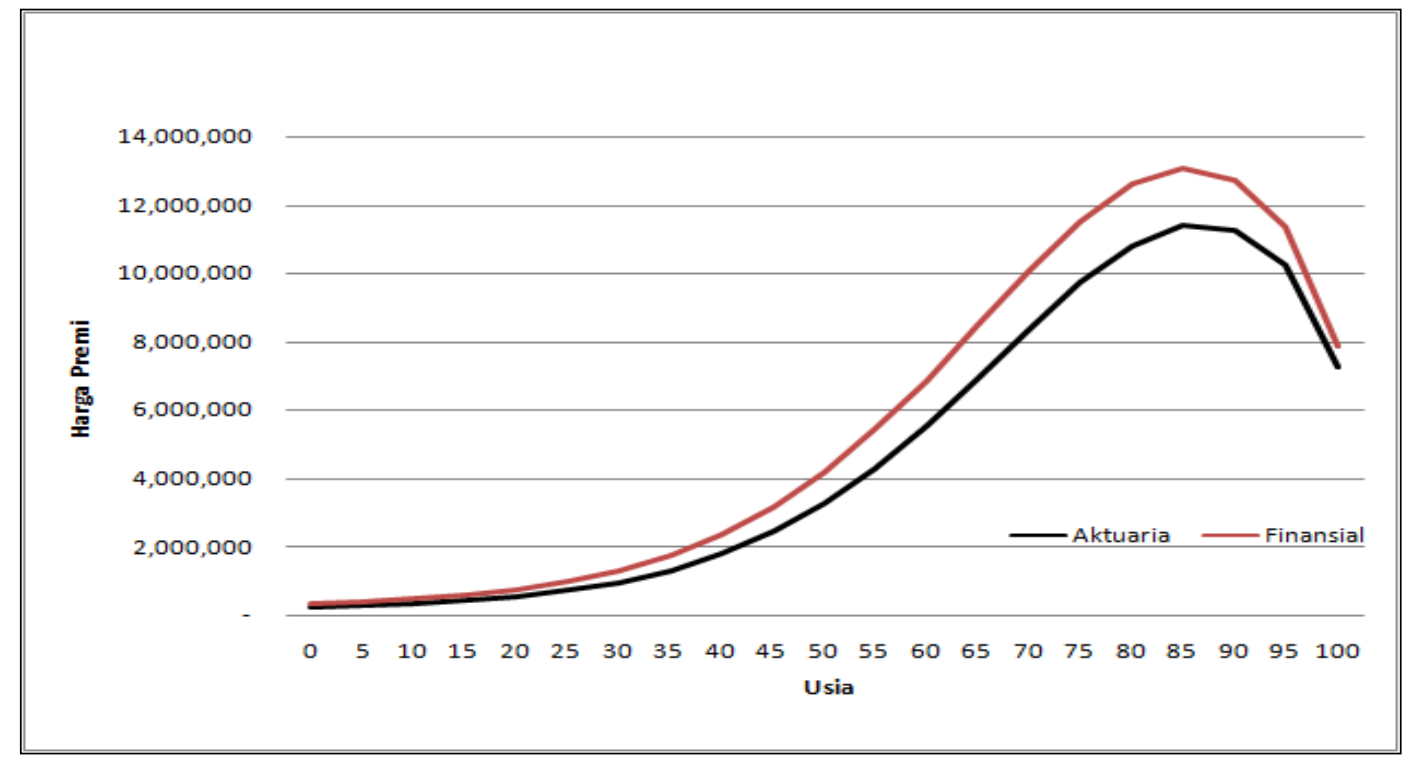

Gambar 1. Grafik hasil perhitungan nilai premi tunggal bersih asuransi jiwa Unit Link dengan usia yang berubah-ubah.

Hasil gambar di atas dapat disimpulkan bahwa, harga premi tunggal bersih asuransi Unit Link akan semakin mahal jika usia nasabah semakin tua sampai mendekati usia 90 tahun, kemudian setelah itu akan turun kembali. Hal ini menjelaskan kepada kita bahwa semakin tinggi peluang hidup seseorang maka semakin murah harga premi yang ditawarkan, tetapi sebaliknya semakin kecil peluang hidup seseorang maka harga premi yang ditawarkan akan semakin mahal. Tetapi hal tersebut tidak berlaku untuk seorang yang berusia di atas 90 tahun karena sisa harapan hidup yang semakin kecil dan peluang kematian untuk usia di atas 90 tahun semakin besar.

Selanjutnya perbandingan harga diantara dua pendekatan aktuarial dan finansial dapat diambil suatu kesimpulan bahwa harga premi dengan pendekatan finansial lebih mahal dibandingkan dengan harga premi menggunakan pendekatan aktuarial, hal ini menjelaskan kepada kita bahwa dengan tingkat suku bunga bebas risiko yang bernilai selalu positif harga premi akan lebih mahal dibandingkan dengan return yang diharapkan dikarenakan return tersebutkan dapat bernilai negatif ataupun melebihi nilai suku bunga yang ditetapkan bergantung terhadap harga saham dipasar. 


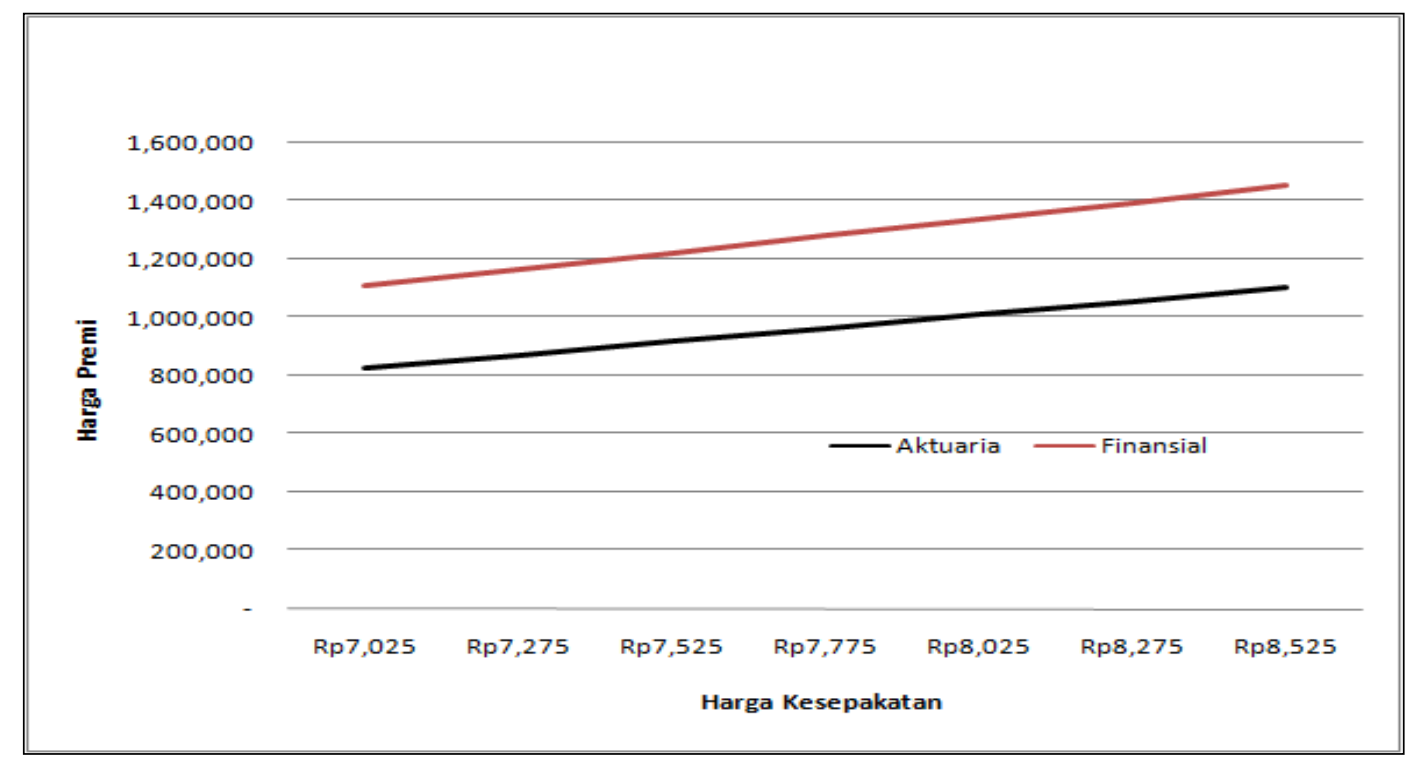

Gambar 2. Grafik hasil perhitungan nilai premi tunggal bersih asuransi jiwa Unit Link dengan harga kesepakatan yang berubah-ubah.

Hasil gambar di atas dapat disimpulkan bahwa, harga premi tunggal bersih asuransi jiwa seumur hidup Unit Link akan semakin mahal jika harga kesepakatan semakin besar. Hal ini menjelaskan kepada kita bahwa jika kita menginginkan hasil investasi yang besar kita harus membayar premi dengan harga yang lebih mahal.

Selanjutnya perbandingan harga diantara dua pendekatan aktuarial dan finansial dapat diambil suatu kesimpulan bahwa harga premi dengan pendekatan finansial lebih mahal dibandingkan dengan harga premi menggunakan pendekatan aktuarial, hal ini menjelaskan kepada kita bahwa dengan harga premi yang lebih murah dan harga kesepakatan yang sama, kita sebagai nasabah akan lebih memilih membeli premi asuransi Unit Link menggunakan pendekatan aktuarial.

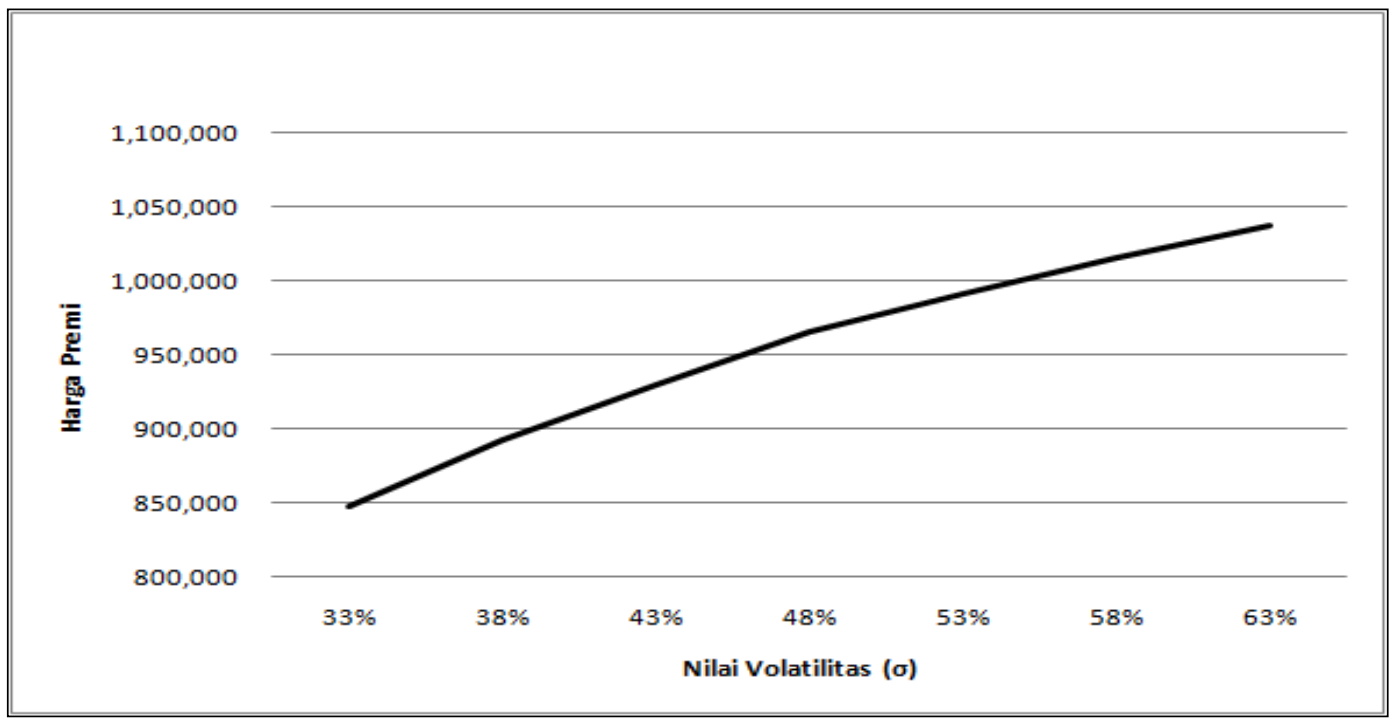

Gambar 3. Grafik hasil perhitungan nilai premi tunggal bersih asuransi jiwa Unit Link pendekatan aktuarial dengan nilai volatilitas yang berubah-ubah. 


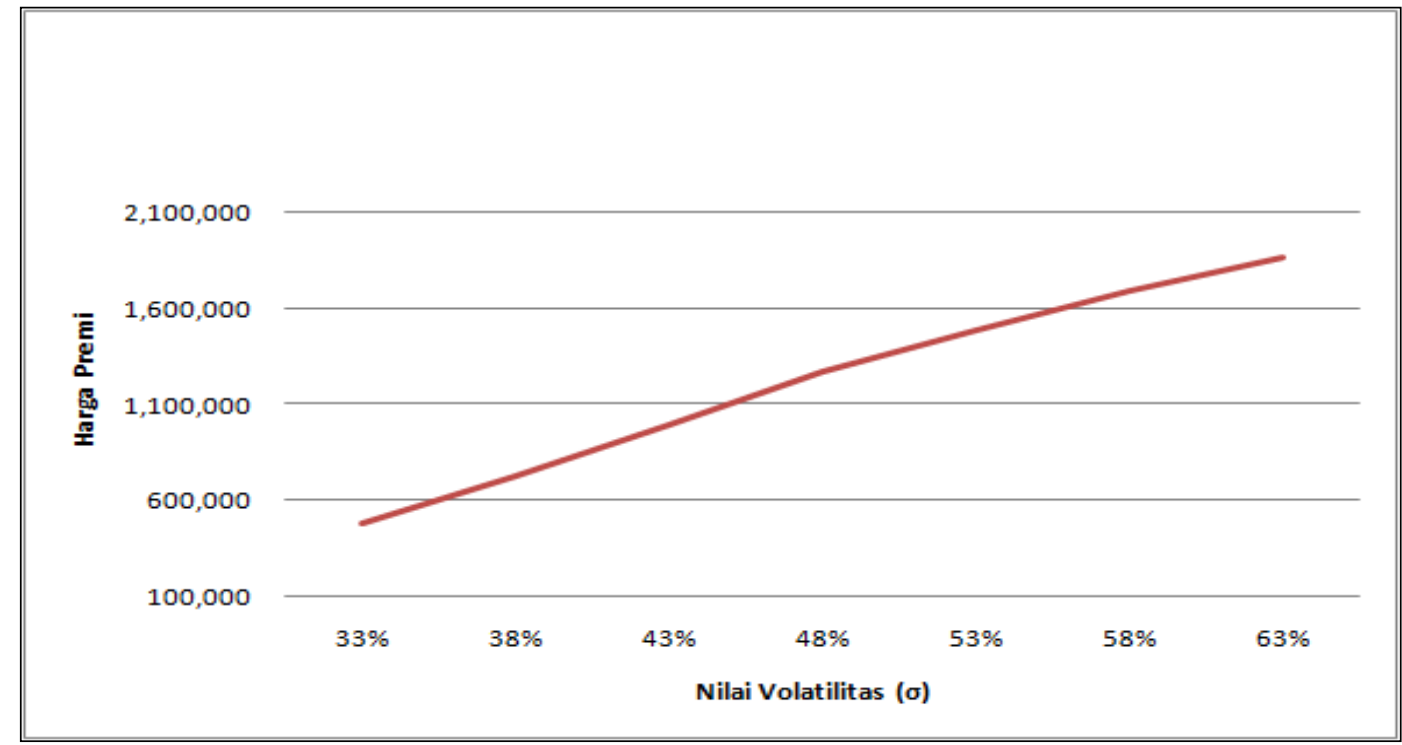

Gambar 4. Grafik hasil perhitungan nilai premi tunggal bersih asuransi jiwa Unit Link pendekatan finansial dengan nilai volatilitas yang berubah-ubah.

Hasil gambar di atas dapat disimpulkan bahwa, harga premi tunggal bersih asuransi jiwa seumur hidup Unit Link akan semakin mahal jika nilai volatilitas semakin besar. Selanjutnya perbandingan harga diantara dua pendekatan aktuarial dan finansial dapat diambil suatu kesimpulan bahwa harga premi dengan pendekatan finansial sangat sensitif terhadap perubahan nilai volatilitas tetapi hal ini tidak berlaku untuk pendekatan aktuarial. Premi Unit Link pendekatan aktuarial cenderung tidak terlalu berpengaruh terhadap perubahan nilai volatilitas yang signifikan. Oleh karena itu dengan kecenderungan nilai volatilitas di Negara kita yang cenderung berubah-ubah secara signifikan maka akan lebih menguntungkan jika kita lebih memilih membeli premi asuransi Unit Link menggunakan pendekatan aktuarial.

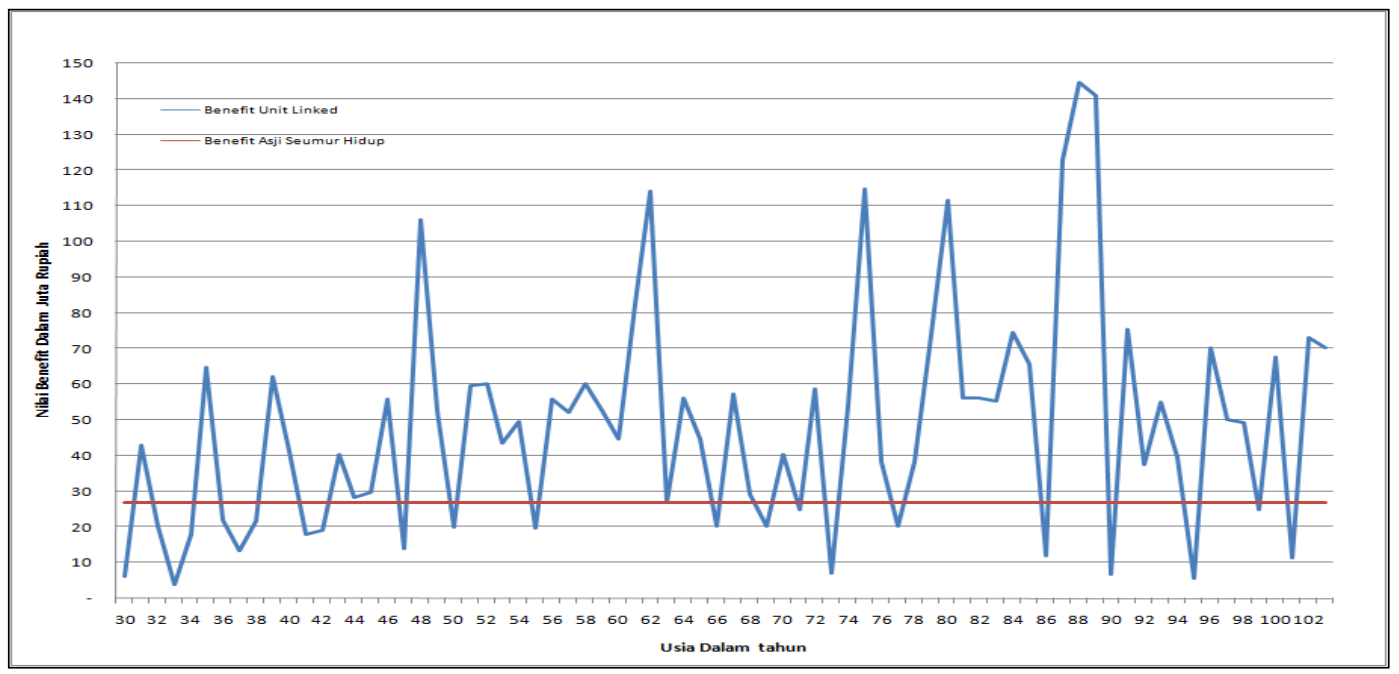

Gambar 5. Grafik perbandingan benefit yang didapat dari asuransi Unit Link pendekatan Aktuarial dan asuransi jiwa seumur hidup untuk usia 30 tahun. 
Gambar di atas menjelaskan bahwa dengan membeli suatu polis asuransi jiwa seumur hidup, akan mendapatkan benefit yang tetap kapan pun nasabah tersebut mati sesuai dengan perjanjian di awal kontrak. Sedangkan besarnya benefit berkorelasi linier dengan besar premi yang dibayar, artinya semakin besar premi yang dibayar untuk asuransi jiwa seumur hidup maka akan semakin besar pula benefi yang didapat, begitu pun sebaliknya.

Hal yang sangat berbeda akan didapat pada saat seseorang nasabah tersebut membeli asuransi jiwa Unit Link, karena benefit yang didapat sangat bergantung dengan harga saham. Semakin besar selisih suatu harga saham dipasar dengan harga kesepakatan maka keuntungan yang didapat akan semakin besar, tetapi sebaliknya jika harga saham dipasar mendekati harga kesepakatan yang telah ditentukan maka akan semakin kecil pula benefit yang didapat. Sampai pada suatu saat pembeli polis asuransi Unit Link tidak akan mendapat adapun atas benefitnya jika harga saham pada saat terjadinya kematian sama dengan harga kesepakatan yang telah ditentukan pada awal kontrak. Hal ini akan berlaku untuk setiap usia nasabah yang membeli kontrak asuransi jiwa Unit Link pendekatan aktuarial.

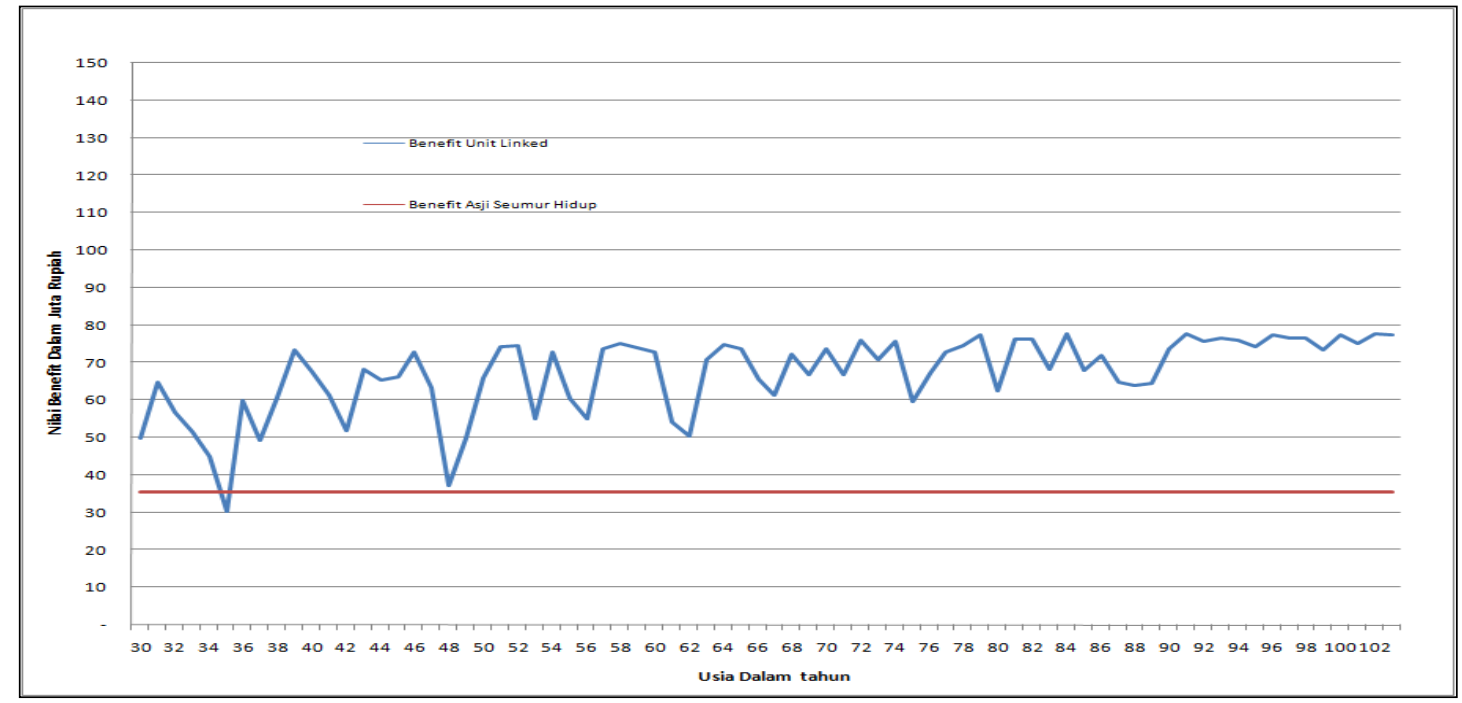

Gambar 6. Grafik perbandingan benefit yang didapat dari asuransi Unit Link pendekatan Finansial dan asuransi jiwa seumur hidup untuk usia 30 tahun.

Hal yang hampir sama juga berlaku untuk pendekatan finansial, dari gambar di atas dapat dijelaskan bahwa dengan membeli suatu polis asuransi jiwa seumur hidup, akan mendapatkan benefit yang tetap kapan pun nasabah tersebut mati sesuai dengan perjanjian di awal kontrak.

Sedangkan untuk asuransi jiwa Unit Link karena benefit yang didapat sangat bergantung dengan harga saham. Semakin besar selisih suatu harga saham dipasar dengan harga kesepakatan maka keuntungan yang didapat akan semakin besar, tetapi sebaliknya jika harga saham dipasar mendekati harga kesepakatan yang telah ditentukan maka akan semakin kecil pula benefit yang didapat.

Selanjutnya perbandingan benefit asuransi Unit Link diantara dua pendekatan aktuarial dan finansial dapat diambil suatu kesimpulan bahwa benefit yang didapat dari asuransi Unit Link menggunakan pendekatan finansial relatif lebih stabil di atas benefit asuransi jiwa seumur 
hidup, berbeda jika menggunakan pendekatan aktuarial, benefit yang akan di dapat cenderung berfluktuatif mengikuti harga saham walaupun rata-rata benefit yang didapat tetap lebih tinggi dari asuransi jiwa seumur hidup. Benefit maksimal yang didapat dari asuransi Unit Link adalah benefit yang menggunakan pendekatan aktuarial dibandingkan dengan pendekatan finansial.

\section{SIMPULAN DAN SARAN}

Temuan yang dapat disimpulkan tentang konstruksi model premi tunggal bersih (Single Pure Premium/SPP) dari asuransi Unit Link dan implementasinya dengan dua pendekatan aktuaria dan finansial serta membandingkan benefit asuransi jiwa seumur hidup dan asuransi Unit Link syariah dengan hasil sebagai berikut:

1. Model premi tunggal bersih asuransi unit link Syariah dengan menggunakan pendekatan aktuarial adalah :

$$
\begin{aligned}
S P P^{A k t} & =\sum_{k=1}^{\omega-x} V^{P}(0, k){ }_{k} p_{x} q_{x+k} \\
& =\sum_{k=1}^{T} K e^{-r k} \Phi\left(-d_{2}^{A k t}(0, k)\right)_{k} p_{x} q_{x+k}-S_{0} \sum_{k=1}^{T} e^{(\mu-r) k} \Phi\left(-d_{1}^{A k t}(0, k)\right)_{k} p_{x} q_{x+k}
\end{aligned}
$$

2. Model premi tunggal bersih asuransi unit link syariah dengan menggunakan pendekatan finansial adalah :

$$
\begin{aligned}
S P P^{F i} & =\sum_{k=1}^{\omega-x} V(0, k){ }_{k} p_{x} q_{x+k} \\
& =\sum_{k=1}^{T} K e^{-r k} \Phi\left(-d_{2}^{F i}(0, k)\right)_{k} p_{x} q_{x+k}-S_{0} \sum_{k=1}^{T} \Phi\left(-d_{1}^{F i}(0, k)\right)_{k} p_{x} q_{x+k}
\end{aligned}
$$

3. Jika seorang nasabah menginginkan return yang maksimal dari suatu produk asuransi maka produk asuransi unit link Syariah merupakan pilihan yang lebih baik.

4. Semakin tinggi usia seorang nasabah dan semakin besar harga kesepakatan maka harga premi asuransi Unit Link syariah yang ditawarkan akan semakin mahal.

5. Benefit yang didapat dari asuransi Unit Link syariah secara rata-rata akan lebih besar jika dibandingkan dengan asuransi jiwa seumur hidup, benefit maksimal akan didapat asuransi Unit Link syariah menggunakan pendekatan aktuarial dibanding finansial, tetapi benefit dengan pendekatan finansial relatif lebih stabil dibanding pendekatan aktuarial yang cenderung berfluktuatif.

\section{DAFTAR PUSTAKA}

Ali, AM. \& Hasan, (2004). Asuransi dalam Perspektif Hukum Islam: Suatu Tinjauan Analisis Historis, Teoritis, dan Praktis. Jakarta: Prenada Media

Anggraini, D., \& Wijaya, Y. (2016). Obligasi Bencana Alam dengan Suku Bunga Stokastik dan Pendekatan Campuran. Al-Jabar: Jurnal Pendidikan Matematika, 7(1), 49-62. 
Boyle, P.P. \& Schwartz, E.S. (1977). Equilibrium prices of guarantees under equity-link contracts, Journal of Risk and Insurance, 44(4), pp. 639-660

Bowers, Newton L, dkk, (1997). Actuarial Mathematics. Second Edition. Schaumburg, Illinois: The Society of Actuaries

Brennan, M.J. \& Schwartz, E.S. (1976). The pricing of equity-link life insurance policies with an asset value guarantee, Journal of Financial Economics, 3, pp. 195-213.

Hamdi, M.L. (2003). Jejak-Jejak Ekonomi Syari'ah. Jakarta, Senayan Abadi, cet ke 2. hal 248

Hardy, M.R. (2000). Hedging and reserving for single-premium segregated fund contracts. North American Actuarial Journal, 4(2), pp. 63-74

Lin, X. Sheldon, (2006). Introductory Stochastic Analysis for Finance and Insurance. Hoboken, New Jersey : Willey \& Sons, Inc

Moller, T. (2003). Indifference pricing of insurance contracts : Applications, to appear in Insurance. Mathematics and Economics.

Ochi, M. K. (1990). Applied Probability and Stochastic Processes: In Engineering and Physical Science. Canada: John Willey \& Sons, Inc

Rinaldi, A. (2015). Aplikasi Model Persamaan Struktural pada Program R (Studi Kasus Data Pengukuran Kecerdasan). Al-Jabar: Jurnal Pendidikan Matematika, 6(1), 1-12.

Sendra, K. (2004). Konsep dan Penerapan Asurasni Jiwa Unit-Link. Jakarta, PPM, hal.21.

Supriadi, N., \& Gunardi, M. S. (2009). Penentuan premi tunggal bersih untuk kontrak asuransi jiwa seumur hidup unit linked (Doctoral dissertation, Universitas Gadjah Mada).

Usman, F. \& Arif, M. (2004). Security For Life: Hidup Lebih Nyaman Dengan Berasuransi, Jakarta. PT. Elek Media Komputindo, hal.30. 